\title{
Determination of risk factors for acute renal failure after cardiac surgery
}

\author{
TA Ayazoğlu*, A Baysal², O Akman³, A Özensoy² \\ From ESICM LIVES 2015 \\ Berlin, Germany. 3-7 October 2015
}

\section{Introduction}

It is vital to determine the risk factors related to acute kidney injury (AKI). The modified RIFLE (risk, injury, failure, loss of kidney function, and end-stage renal failure) classification based on changes in serum creatinine $(\mathrm{sCr})$ relative to the baseline condition may provide valuable data to determine patients in need for renal replacement therapy (RRT) ([1]).

\section{Objectives}

Our aim was to assess perioperative risk factors for AKI for cardiac surgery.

\section{Methods}

We prospectively collected data of 1750 consecutive cardiac surgery patients. AKI was defined by RIFLE system and a modified criteria was included to determine patients with acute need for RRT in the failure class. Risk factors including pre-operative, operative and post-operative variables were investigated by univariate and multivariate analysis.

\section{Results}

The incidence of AKI was $15.3 \%(n=267)$ and of these RRT was performed on $69.6 \%(\mathrm{n}=185)$. The mortality rate among patients with AKI was 54 (20\%) of 267 patients. Preoperative factors causing AKI revealed; angiotensin converting enzyme (ACE) inhibitors, prior recent acute myocardial infact (AMI) (< 6 weeks), euroscore. Postoperative factors causing AKI revealed; cardiopulmonary bypass ( $\mathrm{CPB}$ ) time, need for longer duration of vasoactive drugs and a higher arterial lactate level within 24 hours in ICU ( $\mathrm{p}<0.05)$. Multiple logistic regression analysis revealed; AMI (hazard ratio $(\mathrm{HR})=1.08,95 \%$ confidence interval (CI) 1.01 to $1.15, \mathrm{p}=0.03$ ), $\mathrm{CPB}$ time (hazard ratio $(\mathrm{HR})=1.81,95 \%$ confidence interval $(\mathrm{CI}) 1.28$ to $2.56, \mathrm{p}=0.001$ ), and postoperative lactate level on day 1 (hazard ratio $(\mathrm{HR})=10.57,95 \%$ confidence interval $(\mathrm{CI})$ 1.90 to $58.81, \mathrm{p}=0.007$ ), as independent risk factors for RRT. The worst outcomes, including in-hospital mortality, were associated with the worst RIFLE class $(\mathrm{p}<0.001)$.

\section{Conclusions}

In development of AKI, several variables may play role. Our study demonstrated that preoperative recent AMI, $\mathrm{CPB}$ time and postoperative lactate level on day 1 are independent risk factors for RRT after cardiac surgery.

\section{Authors' details}

${ }^{1}$ Medeniyet University Goztepe Research and Training Hospital, Anesthesiology and Reanimation, Istanbul, Turkey. ${ }^{2}$ Kartal Kosuyolu Research and Training Hospital, Anesthesiology and Reanimation, Istanbul, Turkey. ${ }^{3} \mathrm{Via}$ Hospital Sancaktepe, Anesthesiology and Reanimation, Istanbul, Turkey.

Published: 1 October 2015

\section{Reference}

1. Lopez-Delgado JC, Esteve F, Torrado H, Rodríguez-Castro D, Carrio ML, Farrero E, Javierre C, Ventura JL, Manez R: Influence of acute kidney injury on short- and long-term outcomes in patients undergoing cardiac surgery: risk factors and prognostic value of a modified RIFLE classification. Crit Care 2013, 17(6):R293.

doi:10.1186/2197-425X-3-S1-A634

Cite this article as: Ayazoğlu et al.: Determination of risk factors for acute renal failure after cardiac surgery. Intensive Care Medicine Experimental 2015 3(Suppl 1):A634. 